\title{
Advances observed in papaya tree propagation
}

\author{
Adelaide de Fátima Santana da $\operatorname{Costa}^{1}$, Emanuel Felipe Medeiros Abreu ${ }^{2}$, Edilson Romais Schmildt ${ }^{3}$, \\ Aureliano Nogueira da Costa ${ }^{4}$, Omar Schmildt ${ }^{5}$
}

\begin{abstract}
Papaya (Carica papaya L.) is a fruit tree of great economic and food interest worldwide. Its propagation can occur both sexually and asexually. Traditionally, it is propagated by seeds; however, vegetative propagation has been often used with the use of in vitro and ex vitro culture techniques. In vegetative propagation, the cutting method has been extensively explored. Research has also been developed using grafting. In recent years, papaya cultivation has also become a model for other fruit plants in the use of biotechnological techniques aiming applications ranging from germplasm conservation to genetic transformation of plants. Since the beginning of the 1970 s, the culture of papaya tree tissues has been intensely studied, allowing greater control of in vitro development, especially for micropropagation, organogenesis and somatic embryogenesis techniques.
\end{abstract}

Index terms: Carica papaya L.,propagation of papaya,vegetative propagation,somatic embryogenesis.

\section{Avanços observados na propagação do mamoeiro}

Resumo-O mamoeiro (Carica papaya L.) é uma fruteira de bastante interesse econômico e alimentar em todo o mundo. Sua propagação pode ocorrer tanto por via sexuada como assexuada. Tradicionalmente é propagado por sementes, entretanto, a propagação vegetativa vem sendo frequentemente utilizada com o uso de técnicas de cultura in vitro e ex vitro. Na propagação vegetativa o método de estaquia tem sido bastante explorado. Pesquisas também tem sido desenvolvidas utilizando-se a enxertia. A cultura do mamoeiro tem se tornado também, nos últimos anos, um modelo para outras fruteiras no que diz respeito ao uso de técnicas biotecnológicas, visando aplicações que vão da conservação de germoplasma a transformação genética de plantas. Desde o início da década de 70, a cultura de tecidos do mamoeiro vem sendo intensamente estudada, permitindo maior controle do desenvolvimento in vitro, especialmente para as técnicas de micropropagação, organogênese e embriogênese somática.

Corresponding author: adelaidecosta251@gmail.com

Received: June 21, 2019.

Accepted: October 03, 2019.

Copyright: All the contents of this journal, except where otherwise noted, is licensed under a Creative Commons Attribution License.
Termos de Indexação: Carica papaya L.,Propagação seminifera, propagação vegetativa, cultura de tecidos. 


\section{Introduction}

The improvement of the cultural practices of papaya (Carica papaya L.) with the use of innovative technologies and new cultivation methods has led to significant increases in crop productivity and fruit quality.

For the papaya culture to reach high yields and fruit quality, several factors are directly involved, such as the genetic constitution of the cultivar (superior varieties and / or hybrids), favorable edaphoclimatic conditions, quality seedlings, efficient phytosanitary control, water needs and correction of nutritional deficiencies, therefore directly depending on suitable cultural treatments from planting to harvesting.

Seminiferous propagation continues to be traditional for the formation of commercial plantations in Brazil and must follow the standards of quality seed requirements. The use of hermaphrodite mother plants with self-pollinated flowers is an ideal condition for the production of seeds of the "Solo" group (homozygous cultivars), providing commercial fruit production with typical characteristics of the variety.

The species of the family Carecaceae, as well as the different commercial papaya varieties are traditionally propagated by means of seeds. However, asexual propagation has been frequently used with the use of different in vitro and ex vitro culture techniques, such as cuttings, grafting and tissue culture techniques.

Vegetative propagation by cuttings and grafting are technologies widely used in other fruit trees, which aim to maintain the desirable characteristics of the mother plant, as well as to obtain production precocity.

Positive results for papaya have been reached with propagation by cutting, but it must be analyzed in a comparative way with traditional propagation by seeds, as for its technical and economic feasibility, for use in commercial scale.

Tissue culture plays a key role in the manipulation of plants. Among the in vitro propagation techniques, micropropagation, organogenesis and somatic embryogenesis have been highlighted as the main methods used in the regeneration of several plant species for the most varied purposes. In C. papaya, clonal propagation has been one of the focuses of recent research works.

\section{Seminiferous propagation}

The seminiferous propagation of papaya varieties had a significant evolution over the years, which allowed the production of quality seeds, due to the formation of seed production fields, with the selection of mother plants with desirable characteristics, both for plants and for fruits in isolated areas or using the controlled pollination process.

C. papaya L. species, considered an allogama plant, presents female, male or hermaphrodite plants (STOREY, 1938; ALLAN, 2013) and the populations are dioecious (female and male plants), ginoic-andromonoic (female and hermaphrodite plants) or andromonic-trioic (female, hermaphrodite and male plants). The selection practiced by man favored hermaphroditism (STOREY, 1976) and in this way, most commercial cultivars known in the world are made up of ginoic-andromonoic populations, among them 'Waimanalo', 'Sekati', 'Eksotica', 'JS12 'Maradol', 'Coorg Honey Dew', 'Red Lady', hybrid 'Tainung 01', 'Rubi Incaper 511', hybrid 'UENF / Caliman 01', 'Sunrise Solo', 'Kapoho Solo', 'Baixinho de Santa Amalia 'and' Golden '. In these cultivars, the interest is on hermaphrodite plants, whose fruits have more commercial acceptance than fruits from female plants.

The offspring from self-fertilized flowers of hermaphrodite plants will give rise to $66.67 \%$ hermaphrodite plants. When it comes to the $\mathrm{F}_{1}$ planting from hybrids such as 'Tainung 01 ', only $50 \%$ of plants will be hermaphrodites. Therefore, since the propagation of papaya tree is usually sexed and the floral type of the plant is not known visually before flowering, it is necessary to prepare and plant more than one seed per pit (ALLAN, 2013, SCHMILDT et al., 2015), with financial investment for the preparation of seedlings, conduction, fertilization, and irrigation of plants that will later be thinned leaving only one hermaphrodite seedling per pit.

For varieties and $F_{1}$ from hybrids of ginoicandromonoic populations, it has been recommended to plant three and four seedlings per pit from seminiferous propagation, respectively, which provides, after proper sexing (thinning of female seedlings), about $95 \%$ of hermaphrodite plants, as demonstrated by Schmildt et al. (2015). The use of more than four seedlings per pit is not recommended due to the low final increase of pits with hermaphrodite plants (SCHMILDT et al., 2015) and to increase production costs, in addition to affecting plant growth and initial development of hermaphrodites plants due to competition (FITCH et al., 2005).

In some parts of the world, papaya cultivars from dioecious populations such as 'Cariflora', 'Califlora', 'Coimbatore 01', 'Coimbatore 02', 'Sunnybank', 'Hortus Gold' and 'Honey Gold' are planted. In these cultivars, the commercial interest relies on female plants. Seeds harvested in these plants will give $50 \%$ of female plants and $50 \%$ of male plants. Therefore, also for these cultivars, planting using seminiferous propagation needs to use more than one seedling per planting pit in order to assure as many female plants as possible after proper sexing.

The decharacterization of cultivars can also occur with the propagation of papaya by seeds, when farmers use seeds from commercial fruit production without observing the development characteristics of plants and fruit 
quality and without effective control of the pollination, which is a common practice in crops from the "Solo" group (COSTA et al., 2003) and can increase the genetic heterogeneity of crops. Other authors also report that the seminiferous propagation of papaya without proper care in the field of seed production can lead to variations in offspring, causing decharacterization of genotypes, compromising crop quality (SOOKMARK, TAI, 1975; SENTHILKUMAR et al., 2014). The production of hybrid seeds, such as genotypes from the "Formosa" group, occurs in a differentiated way, being carried out only by companies that own the parents, and the production of seeds by farmers is not recommended, since generations from $\mathrm{F}_{2}$ already present segregation and their use for new plantations leads to the effective decharacterization of genotypes. Schmildt et al. (2015) warn that the planting of seeds of these generations is not recommended because it decharacterizes the cultivar regarding the shape and mass of fruits, and increases the susceptibility of plants to diseases, among other factors.

For the specific case of 'Rubi Incaper 511' genotype, for being a non-hybrid variety from the "Formosa" group, seed production follows the same protocol as the "Solo" group (CATTANEO et al., 2010). Seeds from commercial production areas can be used, provided that the recommendations for the production of quality seeds are met.

Studies have also been carried out on the early identification of the sex of papaya plants by means of phenological markers, but still without success. However, some studies point out that it is possible to identify early sex in papaya by means of molecular markers (DEPUTY et al., 2002; OLIVEIRA et al., 2007; CHAVES-BEDOYA et al., 2009), although this type of analysis is not yet economically feasible for application in the sex distinction of seedlings for planting. Schmildt et al. (2015) reported that, with the same objective, chlorophyll fluorescence emission images have been applied in partnership between researchers from the State University of Norte Fluminense, Brazil and the United States Department of Agriculture (USDA).

\section{Vegetative propagation}

The use of vegetative propagation by means of cutting or grafting constitutes an important practice to obtain clonal plants, with characteristics identical to the mother plant.

Considering the factors mentioned above on the limitations of seed propagation for papaya cultivation, the interest in vegetative propagation has increased in search of the adequacy of this method to enable the production of seedlings for use in commercial plantations. Caple and Cheah (2016) highlight among the negative aspects the genetic heterogeneity among seedlings, which can lead to the absence of uniformity in fruit size, flavor and shape; in addition to sexual variation among individuals.

In papaya cultivation, the regeneration of plants from vegetative branches detached from the mother plant and submitted to the appropriate conditions for rooting and initial growth became a reality with research works developed in South Africa from the 1960's (ALLAN, 1964).

The main advantage of vegetative propagation is the possibility of establishing crops with $100 \%$ hermaphrodite plants for cultivars of ginoic-andromonoic populations (SCHMILDT et al., 2016). For dioecious cultivars, female plants are maintained by vegetative propagation and some male plants to ensure pollination (SENTHILKUMAR et al., 2014). It is noteworthy that there is a market of seedless fruits for papaya and, in this case, also for dioecious cultivars, $100 \%$ of female plants obtained by vegetative propagation are established.

Allan (2007) reports that although the cost of cutting seedlings is higher than seminiferous propagation plants, good pruning practices can keep them in production for a longer period and dilute the initial cost of seedlings. Thus, Allan (2013) reports that in South Africa, where 'Honey Gold' has been planted by cutting for about 50 years, it is possible to maintain productive plants for up to 15 years, since in this country there are no serious problems with viral diseases in papaya.

Allan (2007) reported that the cost of seedlings obtained by cutting should not be generalized for the process of vegetative propagation of papaya, since there are no studies comparing the cost of seminiferous propagation crops with the alternatives of cutting, grafting and tissue culture. Cutting seedlings reported by Allan (2007) depend on heated beds due to the low winter temperatures in South Africa. For the tropical conditions of Brazil, Schmildt et al. (2016) reported the production of 'UENF / Caliman 01' papaya seedlings by cutting without using heated bed, which certainly reduces the production cost. However, in Brazil and in other parts of the world, unlike South Africa, there are serious problems with viral diseases and seedlings must be produced with sufficient sanitary criteria, such as the management of mother plants and the production of cuttings in the greenhouses with anti-aphid screen (SCHMILDT et al., 2015).

Thus, by vegetative propagation, there is the possibility of maintaining the characteristics of the mother plant as well as several advantages, such as higher yield, lower fruiting height and longer cultivation longevity (ALLAN, 2007; CHONG et al., 2008; SENTHILKUMAR et al. Al., 2016).

\section{Cutting}

The first reports of clonal propagation of papaya by cutting were made by Allan $(1964,1967)$, with female plants of "Hortus Gold" cultivar in South Africa. From "Hortus Gold" cultivar, "Honey Gold" cultivar was 
selected, with fruits with higher sugar content, which made it interesting to maintain the genotype by vegetative propagation. The "Honey Gold" cultivar was the subject of further studies on propagation by cuttings over several years (ALLAN, 1981, 1990, 1993, 1995, 2003, 2007, ALLAN et al 1987, ALLAN, MacMILLAN 1991, ALLAN, CARLSON, 2007).

Until 1990, references to cutting propagation were restricted to studies conducted with 'Hortus Gold' and 'Honey Gold' genotypes in South Africa. Since 1990, studies have begun to expand to other parts of the world. Reuveni and Shlesinger (1990) tested this technology in Israel with ' $9 / 13$ ', ' 15 / 1 'and ' 15 / 8' clones. Costa and Costa (1996) worked in the edaphoclimatic conditions of the northern state of Espírito Santo, Brazil, with "Improved Sunrise Solo Line 72/12" cultivar and with Tainung 01 hybrid and observed that the seedlings produced with the use of this methodology without heating of the rooting bed, present good growth and vegetative vigor, plants with lower height of insertion of the first fruits, as well as with reduced vegetative period, and with fruit production seven months after final planting. Other works were developed by Ramkhelawan et al. (1999) in Trinidad, Katoh and Ooishi (2003) in Japan with "Taino 02" cultivar, Fitch et al. (2005) in the United States with "Rainbow" transgenic hybrid. Costa and Pacova (2003) emphasized the importance of this method as a tool to accelerate both the classical and non-conventional breeding process, mainly due to the maintenance of the mother plant characteristics and the reduction of the vegetative period of clonal plants.

In Brazil, this technology has once again aroused the interest in the works of Oliveira (2014) with $\mathrm{F}_{1}$ from 'Uenf / Caliman 02' hybrid; Schmildt et al. (2015) with Golden and THB varieties and Schmildt et al. (2016) with $\mathrm{F}_{1}$ from 'UENF / Caliman 01' hybrid and Golden variety. These recent works have brought important contributions to papaya propagation by cutting, in relation to the differentiated behavior among cultivars in the rhizogenesis of cuttings (SCHMILDT et al., 2016), application of the semi-hydroponic system in the rooting of cuttings (OLIVEIRA, 2014; SCHMILDT et al. Al., 2015) and rooting physiology (SCHMILDT et al., 2016).

In the process of cutting propagation, the first questions are about how to obtain cuttings and what are their dimensions, which according to Allan (1964), for efficient rooting, they should have between 12.7 and $30.5 \mathrm{~cm}$ in length and $2.54 \mathrm{~cm}$ in diameter. Later, the same researcher reported efficiency with the use of smaller cuttings, with length between 5 and $15 \mathrm{~cm}$ and diameter between 0.8 and $1.2 \mathrm{~cm}$ (ALLAN, 1993). Other researchers have used cuttings less than $10 \mathrm{~cm}$ in length (Reuveni and Shlesinger, 1990; Oliveira, 2014), which Schmildt et al. (2015) called minicuttings, which has as a great advantage in relation to the use of macro-cuttings the fact of occupying less space in the nursery.

Obtaining sufficient amount of cuttings requires pruning because the formation of natural shoots in the field is irregular throughout the year (ONO et al., 2004) and variable among different cultivars (SCHMILDT et al., 2011). Some researchers have indicated, in addition to pruning, the use of plant regulators to increase the amount of cuttings per plant (Allen et al., 1993; ONO et al., 2004; GIAMPAN et al., 2005). Barros et al. (2009) and Nascimento et al. (2011) have shown that for "Golden" cultivar under the conditions of northern Espírito Santo, the use of plant regulators in adult plants is not required, provided that pruning performed by removing the stem at $2.0 \mathrm{~m}$ from the soil is carried out during the summer. Nascimento et al. (2011) demonstrated that the production of cuttings is efficient by three subsequent prunings followed by 35-day intervals, forming on average 127 shoots per plant in 3.5 months.

Concerning the production of seedlings from macro-cuttings, Allan and Carlson (2007) using female "Honey Gold" papaya plants pointed to rooting between 75 and $95 \%$ of cuttings with the use of AIB auxin (indole3-butyric acid) in the exogenous concentrations of 3000 $\mathrm{mg} \mathrm{L}^{-1}$. However, with similar procedures, Fitch et al. (2005) obtained only $30 \%$ of rooted cuttings of 'Rainbow' cultivar and Schmildt et al. (2016) obtained about 65\% rooting for 'Uenf / Caliman 01' cultivar and less than 20\% for 'Golden' cultivar.

According to Schmildt et al. (2015), the use of cuttings obtained in the field can bring another inconvenience to the process of clonal propagation that is the removal of diseased cuttings, especially the "meleira" steak disease and mosaic viruses, since plants in the field may be diseased, however, with no visible symptoms. This problem is not a limitation for the vegetative propagation of papaya in South Africa, since according to Allan (2013), there are no serious problems with papaya virus in this country. In relation to the "Rainbow" cultivar in the United States, the mosaic virus is not a problem, since it is a resistant transgenic cultivar allowed for commercial planting in that country.

As for the substrate in the macro-cutting, the perlite and vermiculite mixture has been used in a ratio of 1: 1 (FITCH et al., 2005), perlite (ALLAN, CARLSON, 2007) and sand (SCHMILDT et al., 2016). In this work, Schmildt et al. (2016) verified that "UENF / Caliman 01" cultivar seedlings from macro-cuttings maintained a good water status and photosynthetic rate regardless of the volume of roots formed.

Considering the difficulties in the process with the use of field cuttings, Schmildt et al. (2015) suggest that the process could bring many advantages if cuttings were obtained in greenhouse, as suggested by Reuveni and Shlesinger (1990), who obtained cuttings with a maximum of $7.2 \mathrm{~cm}$ in length and with $92 \%$ of rooting when treated 
with IBA at $1000 \mathrm{mg} \mathrm{L}^{-1}$.

The procedure adopted by Reuveni and Shlesinger (1990) was used by several researchers to obtain shoots for cutting (OLIVEIRA, 2014; SCHMILDT et al., 2015) or for grafting (LIMA et al., 2010). It is noteworthy that for the Brazilian conditions, the greenhouse must be protected with anti-aphid screen as recommended by Lima et al. (2010) and by Schmildt et al. (2015).

Oliveira (2014), working with min-cutting of 'UENF / Caliman 02' papaya cultivar, emphasizes that the process, in addition to using reduced space in the nursery and producing safer seedlings, has the advantage of being less expensive with the use of auxin in rooting. According to this author, using $6 \mathrm{mg} \mathrm{L}^{-1}$ of AIB, $62 \%$ of rooting of "Uenf / Caliman 02" $\mathrm{F}_{1}$ mini-cuttings was obtained, while the use of macro-cuttings requires 1000 to $4000 \mathrm{mg} \mathrm{L}^{-1}$ of IBA. However, it should be noted that Oliveira (2014) worked with rooting of cuttings in semihydroponic system, which effectively contributed to the success of the rooting rate obtained.

The semi-hydroponic system in greenhouse proposed by Oliveira (2014) follows the following steps: a) obtaining mother plants by seminiferous propagation to form the clonal mini-garden, using pots with capacity of 25 L containing mixture of soil + sand + bovine manure as substrate (3: 1: 1 , by volume); b) sexing of seedlings maintaining only hermaphrodites; c) decapitation of the upper part leaving only the stem with about $1.5 \mathrm{~m}$; d) three applications of plant regulators $\left(300 \mathrm{mg} \mathrm{L}^{-1}\right.$ benzyl aminopurane (BAP) $+100 \mathrm{mg} \mathrm{L}^{-1}$ of $\mathrm{GA}_{3}$ ) in the remaining stem at intervals of one week between applications; e) successive prunings and in each pruning, part of the branch is left with one to two knots to form new shoots (the amount of shoots formed is increased at each pruning, which is between 5 and $10 \mathrm{~cm}$ and are used as mini-piles); f) fixation of piles in cells of styrofoam trays, using as substrate coconut fiber or vermiculite, in which styrofoam trays are placed inside white trays containing nutrient solution, following recommendation of Furlani et al. (1999) and AIB for one week; g) exchange of the nutrient solution by another of the same constitution, according to Furlani et al. (1999) but without AIB. The system was also efficient for 'Golden' and 'THB' cuttings (SCHMILDT et al., 2015).

\section{Grafting}

Grafting is characterized by the junction of the tissues of two plants, between the upper part called epibiote ("scion", graft) on the underside, the hypobiote ("rootstock") of another cultivar or species (HARTMANN et al., 2011). One of the first records on the vegetative propagation of papaya by grafting was reported by Hancock (1940), grafting branches of female plants on male plants of the same dioecious cultivar, directly in the field. Field grafting has also been reported by Airi et al.
(1986) for "Coorg Honey Dew" and "Coimbatore 01" cultivars.

In the search for greater viability in the production of grafted seedlings, Chong et al. (2008) working with "Eksotika" cultivar produced seedlings in nursery using as rootstock plants obtained by seminiferous propagation and as graft, lateral shoots obtained from mother adult plants in the field. The same system was reported by Allan et al. (2010) and by Allan (2013) for "Honey Gold" cultivar. For this case, in the production of seedlings, Allan (2013) used bags of $15 \mathrm{~cm}$ in height and $10 \mathrm{~cm}$ in diameter and 1 L of substrate.

Lima et al. (2010), in a study conducted in Brazil, produced 'Sunrise Solo', 'Golden' and 'Tainung 01' seedlings using 'Tainung 01 ' $\mathrm{F}_{2}$ plants as rootstock obtained by seminiferous propagation. Unlike what had been performed by Chong et al. (2008) and by Allan et al. (2010), mother plants for the removal of grafts were kept in greenhouse with anti-aphid screen protection.

More recently, Nava et al. (2011) working with "Maradol" cultivar used branches obtained by tissue culture as graft. This system used by Nava et al. (2011), if improved can be very interesting from the economic point of view because seedlings occupy less space in the nursery, since rootstocks are prepared in tubes.

Grafting is also interesting when characteristics of higher rusticity are searched in rootstocks (CHONG et al., 2008). Thus, grafting was also verified between different genera and species of the Caricaceae family (JIMÉNEZ, 1957; RICELLI, 1963). Jiménez (1957) reported good compatibility in the graft between Varconcellea cauliflora and Carica papaya, V. microcarpa and C. papaya, $V$. monoica and C. papaya.

Regarding the grafting process efficiency, Allan et al. (2010) reported that the main problem is loss of seedlings by bacterial contamination in the graft region. Schmildt et al. (2015) in a study carried out in Spain with "BH65" dwarf cultivar reported that the main secret to the grafting efficiency is the size of 'cells' of trays and the substrate, which should retain minimum water.

As for the grafting process, Airi et al. (1986) and Chong et al. (2008) used V-grafting and Allan (2013) used the splice grafting method. Normally, the diameter of rootstock stems varies between 4 and $10 \mathrm{~mm}$ (Alan et al., 2010, LIMA et al., 2010, ALLAN, 2013). For grafting in the field, Sookmark and Tai (1975) report grafting with diameter of around $15 \mathrm{~mm}$.

Schmildt et al. (2015) reported that in Almeria, Spain, splice grafting has been successfully used in tomato species and is also efficient in the auto-graft of ' $\mathrm{BH} 65$ ' papaya, which grafting process, biodegradable tweezers are used for "scion" and "rootstock" junction, making the system much faster, moving toward automation of the process as mentioned by Lee et al. (2010).

Peçanha et al. (2010) studied the physiological 
aspects of 'Solo', 'Golden' and 'Tainung 01' grafted seedlings and verified that transpiration and stomatal conductance were not affected by 'Tainung 01 ' rootstock and the new xylem connection seems to keep the roottrunk-atmosphere system stable.

In order to reduce flowering height and to anticipate fruit production, Lange (1969) was successful with the grafting of 'Solo Line 8' on a dwarf lineage. This system may be of interest for protected cultivation, as in southern Spain, where smaller plants are used for commercial cultivation in greenhouses (ROBLEDO and GONZÁLEZ, 2009).

\section{Tissue culture}

Plant tissue culture can be defined as a set of axenic cultivation techniques of different types of plant cells, tissues and organs for regeneration of a whole individual. This tool plays a key role in the manipulation of plants, since it has aided in classical genetic improvement, biotechnology, germplasm conservation, plant health and more recently in advanced biology studies such as genomics, proteomics and metabolomics (VAN DROOGENBROECK et al., 2002; MING et al., 2008; YU et al., 2009; DHEKNEY et al., 2016).

Among the in vitro propagation techniques used in tissue culture, micropropagation, organogenesis and somatic embryogenesis have been highlighted as the main methods used in the regeneration of several plant species for the most varied purposes. In C. papaya, these methods are applied, mainly, to aid in the classical genetic improvement, allowing the crossing between different species of the Caricaceae family (DREW et al., 1998; VAN DROOGENBROECK et al., 2005), clonal propagation (WU et al., 2012; SERTAGIE et al., 2015), maintenance of in vitro germoplasms (TSAI et al., 2009) and generation of transgenic plants, especially for virus resistance (CAI et al., 1999; SOUZA JUNIOR. et al., 2005; MISHRA et al., 2016).

\section{Micropropagation}

The first works with $C$. papaya micropropagation started four decades ago (MEHDI, 1975; YIE; LIAW, 1977). Both studies used seedling buds in which there was limited sex determination of initial explants for being young tissues. Later, Litz and Conover (1977, 1978a, 1981) reported successful regeneration of papaya plants by culture of adult plants from the field. Another approach that resulted in a rapid development of axillary branches from adult field-grown plants was developed by Drew (1988). In this work, the apical meristem of adult plants was removed and in the cut region, a solution containing $225 \mathrm{mg} \mathrm{L}^{-1} \mathrm{BAP}$ was applied. A few weeks after treatment, new axillary buds emerged and were used as explants for the micropropagation of shoots grown on Drew and Smith (DS) medium supplemented with $0.2 \mathrm{mg} \mathrm{L}^{-1} \mathrm{BAP}$ and $0.1 \mathrm{mg} \mathrm{L}^{-1}$ naphthaleneacetic acid (NAA). In the rooting phase of new shoots, reduced concentrations of DS salts and IBA concentration of $2 \mathrm{mg} \mathrm{L}^{-1}$ were used in the medium. The results obtained in these first studies created new perspectives in the mass propagation from plants with determined sex, a factor of extreme relevance due to the interest for fruits from hermaphrodite plants for commercialization.

For many cultivated plants, where production can occur by vegetative propagation, as is the case of papaya, micropropagation stands out as a very advantageous tool, as its ability to produce a large number of homogenous plants can eliminate the negative aspects of seed propagation (WU et al., 2012; CAPLE; CHEAH, 2016). Papaya cloning by in vitro axillary or apical bud culture is currently well-established and relatively used strategy in research with different applications and in private seedling production companies. This technique has been adopted because clonal propagation occurs rapidly, with relatively low cost and high genetic and phytosanitary quality (PATEL et al., 2013; CAPLE; CHEAH, 2016).

Another important aspect of $C$. papaya tissue culture is that this species can be considered sensitive to the effects of plant regulators and ideally, presents rapid in vitro development (WU et al., 2012; SETARGIE et al., 2015). In the micropropagation of shoots, many studies have reported that the most used and suitable plant regulators are BAP and NAA. The effect of the combination of these two plant regulators is directly related to a greater efficiency in the induction time, frequency and growth of shoots (DREW et al., 1988, ROHMAN et al., 2007, SETARGIE et al., 2015). In the elongation phase, the association of BAP with $\mathrm{GA}_{3}$, a gibberellin widely used to restore the apical dominance of adventitious shoots, is common (MONDAL et al., 1990; WU et al., 2012; PATEL et al., 2013; CAPLE; CHEAH, 2016). However, in the rooting induction phase, the protocols with the most promising results, with respect to the rooting time and frequency, culture media with Murashige and Sloog supplemented with IBA at concentrations ranging from 1 to $2 \mathrm{mg} \mathrm{L}^{-1}$ are used, depending on the genotype used (LAI et al., 2000; MUMO et al., 2013; WU et al., 2012; SETARGIE et al., 2015).

When compared to other tissue culture techniques, such as embryogenesis and organogenesis, micropropagation is more adequate to act in the generation of a large number of clones of an elite variety or lineage, in germplasm conservation and clonal cleaning. This fact is due to the shorter time to obtain new plants, low genetic instability and somaclonal variation, common in other in vitro regeneration methods due to the greater exposure to plant regulators (ABREU et al., 2014; KRISHNA et 
al., 2016). However, these variations are unpredictable and are characterized by the occurrence of alterations in the genome of epigenetic nature (SCHELLENBAUM et al., 2008; CLARINDO et al. 2008; SATO et al., 2011b; KRISHNA et al., 2016).

Micropropagation has also been routinely used to support research programs on genetic resources and genetic improvement aimed at developing lineages by interspecific crosses of C. papaya and some of its wild relatives with sexual incompatibility, such as species of the genus Vasconcellea (DREW Et al., 2007). However, in some cases, to obtain papaya lineages from crosses between different species, it is necessary to use micropropagation for the rescue of immature zygotic embryos before the evaluation of adult plants in greenhouse and in the field (VAN DROOGENBROECK et al., 2005). Thus, genotypes of interest can be cloned, shortening the stages of field evaluation regarding their agronomic characteristics necessary for future releases of commercial varieties.

Finally, among the main limitations of papaya tissue culture, regardless of the method of in vitro regeneration, especially of materials from the field, are the establishment of protocols free of contamination by bacteria and endophytic fungi (DHEKNEY et al., 2016). When uncontrolled, these microorganisms can compromise growth, development and in vitro multiplication of shoots and roots. Under field conditions, endophytes are usually not harmful. However, under artificial conditions, such as in vitro cultivation, they may change their behavior, becoming pathogenic microorganisms (DREW, 1988; THOMAS et al., 2007; THOMAS; KUMARI, 2010).

\section{Organogenesis}

Organogenesis is an in vitro regeneration technique in which there is multiplication of adventitious buds directly or indirectly. In papaya and other plant species, either directly or indirectly, there is the development of buds from tissues, such as vascular cambium, petiole base, leaf base, cotyledons, root segments, among others (DREW et al., 1993; CABRERA-PONCE et al., 1996; CLARINDO et al., 2008). In the indirect path, this process is characterized by the formation of buds preceded by calli originating from different sources of explants (GRATTAPAGLIA; MACHADO, 1998). In the organogenesis, as well as in other in vitro propagation methods, the success of these techniques depends on many variables, such as species, genotype, source of explant, environmental conditions, culture medium composition and hormonal balance (PERES, 2002). In literature, in organogenesis protocols, the use of MS medium (MURASHIGE; SKOOG, 1962) as the main source of organic and inorganic compounds is more common (FITCH et al., 2005a; BHATTACHARYA et al., 2003; TETSUSHI et al., 2008; MUMO et al., 2013).
Among hormones or plant regulators in the class of cytokinins, Thidiazuron (TDZ), BAP and kinetin (KIN) stand out; and among auxins, NAA, AIA and IBA are the main phytohormones used in organogenesis (FITCH et al., 2005; TETSUSHI et al., 2008; MUMO et al., 2013; VEENA et al., 2015).

The first step of the organogenesis technique is the step of inducing adventitious buds from tissues responsive to stimuli present in the culture media and environment. Among auxins and cytokinins most used in the induction of regeneration of adventitious buds, BAP and NAA are undoubtedly the most common in protocols. Different BAP and NAA combinations and concentrations tested in many studies presented high efficiency in the induction and proliferation of adventitious buds, from several sources of explants (LAI et al., 1998; AHMAD, ANIS, 2007; ANANDAN et al., 2011). However, Anandan et al. (2011) evaluated the effects of the combination in different BAP and NAA concentrations compared to the exclusive use of TDZ on culture media and found that treatment with a higher number of shoots per explant occurred in MS medium supplemented with $0.5 \mathrm{Mg} \mathrm{L}^{-1}$ TDZ. Therefore, Bhattacharya et al. (2003) evaluated the effect of BAP and NAA combinations compared to TDZ and found that the ratio of $1 \mathrm{mg} \mathrm{L}^{-1} \mathrm{BAP}$ to $0.1 \mathrm{mg} \mathrm{L}^{-1} \mathrm{ANA}$ produced more buds compared to medium supplemented with TDZ at concentration of $0.4 \mathrm{mg} \mathrm{L}^{-1}$. The results obtained in these studies demonstrate that the efficiency of in vitro propagation protocols is directly related to the type of explant and genotype used (DREW, 1988, 1993, ZOBAYED et al., 2004, KOZAI, 2010, PÉREZ et al., 2015).

Therefore, many studies in which $C$. papaya axillary or apical buds were used as sources of explants, BAP, TDZ and other cytokinins have been found to promote the breakdown of the apical dominance, causing the initiation of shoots, while the presence of NAA and other auxins act on the proliferation of cells in the region of meristems (AHMAD; ANIS, 2007; TEIXEIRA DA SILVA, 2014). Another plant hormone widely used in the elongation phase of adventitious buds in many organogenesis protocols is $\mathrm{GA}_{3}$, belonging to the class of gibberellins (KOZAI et al., 2005; TEIXEIRA DA SILVA, 2016).

Currently, one of the major challenges of in vitro regeneration protocols, either by embryogenesis, micropropagation or organogenesis in papaya culture, is the rooting and ex vitro acclimatization stages of regenerated plants. This step has been reported in many papers as being crucial for determining the degree of efficiency of a given in vitro propagation protocol (KOZAI et al., 2005; NORIKANE et al., 2010; BADR et al., 2011; SHIN et al., 2013). In many cases, the loss may reach $70 \%$ of plants produced in vitro (MALABADI et al., 2011; TEIXEIRA DA SILVA, 2016). Thus, different 
hormonal combinations are fundamental to find the most adequate conditions to promote efficient rhizogenesis and, consequently, to allow better performance of regenerated plants in the acclimatization phase. In this scenario, several authors observed the superior effect of IBA in relation to the other auxins used in the in vitro rooting of papaya buds (TEIXEIRA DA SILVA et al., 2007, KUMAR et al., 2012, NZILANI et al., 2013; SEKELI Et al., 2013). In this context, in addition to the hormonal stimuli and other components of the culture medium, an alternative to increase efficiency in the acclimatization conditions is to allow in vitro gas exchanges, promoting greater ventilation of gases produced during the stretching and rooting phases (LAI et al. ., 1998). The type of sealing material used in the in vitro culture is known to influence the growth and development of plants (BUDDENDORF-JOOSTEN; WOLTERING, 1994) and the use of suitable caps have positive effects on the in vitro propagation of papaya, regardless of the techniques used (LAI et al., 1998).

\section{Embryogenesis}

Somatic embryogenesis (SE) stands out as the most studied and used technique for the in vitro regeneration of different $C$. papaya varieties and hybrids (FITCH; MANSHARDT, 1990; FITCH, 1993; RAZUKDAS et al., 2003; RAZALI; DREW, 2014). Many SE protocols using different sources of explants have been established since the 1970s, when the first studies were conducted (DE BRUIJNE et al., 1974; YIE; LIAW, 1977; ARORA; SINGH, 1978). Among the different explants used in SE, the use of hypocotyls (FITCH, 1993; ANANDAN et al., 2012), immature zygotic embryos (CHEN et al., 1987; CLARINDO et al., 2008, ANANDAN et al. 2012), anthers (LITZ; CONOVER, 1978; TSAY; SU, 1985; RIMBERIA et al., 2005) and cotyledons (CABRERAPONCE et al., 1996; HOMHUAN et al., 2008; TEIXEIRA DA SILVA, 2014b) stands out. However, the majority of the studies using SE technique make use of immature zygotic embryos, since this explant presents high embryogenic potential and low index of contamination by microorganisms, unlike adult tissues (RENUKDAS et al., 2003; ASCENCIO-CABRAL et al., 2008; CLARINDO et al., 2008).

The first report of $C$. papaya regeneration by SE was described by De Bruijne et al. (1974), in which embryogenic calli were induced from leaf petioles. A few years later, Yie and Liaw (1977) and Arora and Singh (1978) obtained embryogenic calli from stem segments and leaf petioles, respectively. In these studies, embryogenic calli and somatic embryos were induced in the presence of NAA and kinetin. Subsequently, many studies involving $C$. papaya $\mathrm{SE}$ induction have used different combinations of NAA and kinetin to obtain embryogenic calli and mature somatic embryos. However, many studies involving ES of C. papaya and other species of the same genus, have used different combinations of auxins such as 2,4-D, AIA, picloram and 2,4,5-T associated with different cytokines such as BAP and TDZ. In all of these studies, the efficiency of protocols is directly related to the type of explant and genotypes used (CHEN et al., 1987; FITCH, 1993; VILASINI et al., 2000; CLARINDO et al., 2008; MALABADI et al., 2011; RAZALI; DREW, 2014). In addition, regardless of explant and genotype used, C. papaya has been responsive to SE (VILASINI et al., 2000; CLARINDO et al., 2008; ABREU et al., 2014). It is also worth noting that the use of MS medium at different concentrations (MURASHIG; SKOOG, 1962) supplemented with these phytohormones is predominant among SE protocols developed until now (ANANDAN et al., 2012).

The influence of components of the culture medium is undoubtedly a determining factor in the in vitro regeneration process. In addition to the influence of salts and vitamins on the culture medium, many studies have reported how carbohydrates and their concentration on the culture medium directly affects the efficiency in the induction of somatic embryos of papaya (CHEN et al., 1987; FITCH, 1993; SCHMILDT et al., 2007; MALABADI et al., 2011; ANANDAN et al., 2012). Recently, Heringer et al. (2013) showed that low sucrose concentration $\left(30 \mathrm{~g} \mathrm{~L}^{-1}\right)$ is more efficient in the induction of embryogenic cultures than high concentrations (60 g $\left.\mathrm{L}^{-1}\right)$. The results observed were also consistent for other C. papaya varieties, since SE induction is also dependent on genotype. In another study, Malabadi et al. (2011) used $30 \mathrm{~g} \mathrm{~L}^{-1}$ of sucrose as standard for the induction of papaya embryogenic cultures and verified in 12 varieties that this concentration was the one that presented the best response. Contrasting the results obtained by Malabadi et al. (2011), Anandan et al. (2012) induced embryogenic cultures with $60 \mathrm{~g} \mathrm{~L}^{-1}$ of sucrose, followed by reduction to $30 \mathrm{~g} \mathrm{~L}^{-1}$, which allowed better development of somatic embryos and their maturation. According to Malabadi et al. (2011), the maturation and germination of somatic embryos and acclimatization of plants from SE is a critical step in plant regeneration.

Several agents that promote the maturation and germination of somatic embryos have been used in this process, such as abscisic acid (ABA) and osmotic agents, namely: polyethylene glycol (PEG), carbohydrates, hexitois and floroglucinol (VALE et al., 2014; PÉREZ et al., 2016). These substances have been used in cultures of somatic embryos of many varieties and species to simulate the effects of dehydration that normally occurs in the maturation of zygotic embryos during seed maturation and growth promotion, necessary for the germination phase. In papaya, there are reports that the maturation of somatic embryos at high ABA concentrations shows a positive correlation (ANANDAN et al., 2012). In the absence of ABA, maturation results in poorly developed and often 
abnormal somatic embryos presenting low capacity for germination and seedling development (DETONI, 2013). PEG, which is a cell-inert osmotic agent, induces tissue restriction of water absorption, decreasing turgor pressure and playing a role in reducing intracellular osmotic potential, leading to desiccation. PEG-induced desiccation may stimulate endogenous production of $\mathrm{ABA}$, a plant hormone essential for the synthesis of reserve compounds for the other phases of embryo development (SMULDERS et al., 2011; HERINGER et al., 2013).

Finally, the germination of somatic embryos is also a crucial step and considered a great challenge for papaya regeneration. In this process, the main related problems are the low germination rate due to some factors such as hyperhydricity in the phase of formation of embryogenic calli and callus production at the base of the radicle; which occurs due to the residual effect of plant regulators used in the induction phase, in addition to the malformation of the somatic embryos due to somaclonal variations of different natures (SMULDERS et al., 2011; PÉREZ et al., 2016).

\section{Conclusion}

Seminiferous propagation, although being the most used propagation for papaya, presents negative aspects, among them the genetic heterogeneity and the sexual variation among individuals.

The clonal propagation of papaya has been shown to be promising for use on a commercial scale, which may bring several benefits to the productive system, however, a further improvement of protocols is still necessary.

In asexual propagation, cutting and grafting methods have been shown to be less economically advantageous than tissue culture and their use is limited because of the low rates of ex vitro regeneration and reproducibility of protocols.

One of the major challenges of in vitro regeneration protocols, either by embryogenesis, micropropagation or organogenesis in papaya culture, is the rooting and $e x$ vitro acclimatization stages of regenerated plants, which $\mathrm{s}$

\section{References}

ABREU, I.S.; CARVALHO, C.R.; CLARINDO, W.R. Massal induction of Carica papaya L. 'Golden' somatic embryos and somaclone screening by flow cytometry and cytogenetic analysis. Cytologia, Tokyo, v.79, n.4, p. $475-484,2014$.

AHMAD, N. AND ANIS, M. Rapid plant regeneration protocol for cluster bean (Cyamopsis tetragonoloba L.Taub.). The Journal of Horticultural Science \& Biotechnology, Asford, v.84, p.585-589, 2007.

AIRI, S.K.; GILL, S.S.; SINGH, S.N. Clonal propagation of papaya (Carica papaya L.). Journal of Agricultural Research, Washington, v.23, p.237-239, 1986.

ALLAN P., Vegetative propagation and production of 'Honey Gold' papayas. Acta Horticulturae, The Hague, v.269, p.105-111, 1990. Disponível em: $\leq$ http://www.ishs. org/ishs-article/269 13>

ALLAN, P. Clonal 'Honey Gold' papaws - a horticultural and commercial success. Citrus and Subtropical Fruit Journal, Johannesburg, v.575, p.19-23, 1981.

ALLAN, P. Clonal papaws prove successful: 40-year old clone continues to produce well. South African Fruit Journal, Johannesburg, v.2, p.49-52, 2003.

ALLAN, P. Papaws growth from cuttings. Farming in South Africa, Pretoria, v.39, n.11, p.35-40, 1964.

ALLAN, P. Papaws research at Pietermaritzburg: production from cuttings. Farming in South Africa, Pretoria, v.42, n.11, p.15-21, 1967.

ALLAN, P. Phenology and production of Carica papaya 'Honey Gold' under cool subtropical conditions. Acta Horticulturae, The Hague, v.740, p.217-224, 2007. Disponível em: <http://www.ishs.org/ishsarticle/740 26>.

ALLAN, P. Propagation of 'Honey Gold' papayas by cuttings. Acta Horticulturae, The Hague, v.370, p.99102, 1995. Disponível em: $\leq$ http://www.ishs.org/ishsarticle/370 15>.

ALLAN, P. Propagation of honey gold papaws by cuttings. In: INTERNATIONAL SYMPOSIUM ON TROPICAL FRUITS, 1993, Vitoria. Abstracts... p.23. 
ALLAN, P. Selection and vegetative propagation of superior bisexual papayas. South African Fruit Journal, Johannesburg, v.12, p.38-39, 2013. Disponível em: $\leq$ http:// www.hortgro-science.co.za/wp-content/uploads/2015/09/ Allan-Bisexual-Papayas.pdf $>$.

ALLAN, P., McCHLERY, J.; BIGGS, D. Environmental effects on clonal female and male Carica papaya plants. Scientia Horticulturae, New York, v.32, n.3-4, p.221-232, 1987. Disponível em: $\leq$ http://www.sciencedirect.com/ science/article/pii/0304423887900896>.

ALLAN, P.; CARLSON, C. Progress and problems in rooting clonal Carica papaya cuttings. South African Journal of Plant and Soil, Pretoria, v.24, n.1, p.22-25, 2007. Disponível em: $\leq \mathrm{http}: / /$ www.tandfonline.com/doi/ pdf/10.1080/02571862.2007.10634776>.

ALLAN, P.; CLARK, C.; LAING, M. Grafting papayas (Carica papaya L.). Acta Horticulturae, The Hague, v.851, p.253-258, 2010. Disponível em: $\leq$ http://www.ishs. org/ishs-article/851_38>.

ALLAN, P.; Mac MILLAN, C.N. Advances in propagation of Carica papaya L. cv. Honey Gold cuttings. Journal of the South African Horticulture Science, Pretoria, v.1, n.2, p.69-72, 1991.

ALLAN, P.; TAYLER, S.; ALLWOOD, M. Lateral bud induction and effects of fungicides on leaf retention and rooting of Honey Gold papaws. Journal of the South African Horticulture Science, Pretoria, v.3, n.1, p.5-8, 1993.

A N A N D A N, R.; S U D H A K A R A, D .; BALASUBRAMANIANA, O.; GUTIÉRREZ- MORAB, A. In vitro somatic embryogenesis from suspension cultures of Carica papaya L. Scientia Horticulturae, New York, v.136, p.43-49, 2012.

ARORA, I.K.; SINGH, R.N. Growth hormones and in vitro callus formation of papaya. Scientia Horticulturae, New York, v.8, p.357-361, 1978.

ASCENCIO-CABRAL, A.; PULIDO, H. G.; GARAY, B. R.; MORA, A. G. Plant regeneration of Carica papaya $\mathrm{L}$. through somatic embryogenesis in response to light quality, gelling agent and phloridzin. Scientia Horticulturae, New York, v.118, p.155-160, 2008.

BADR, A.; ANGERS, P.; DESJARDINS, Y. Metabolic profiling of photoautotrophic and photomixotrophic potato plantlets (Solanum tuberosum) provides new insights into acclimatization. Plant Cell, Tissue and Organ Culture, Dordrecht, v.107, p.13-24, 2011.
BARROS, F.L.S.; SCHMILDT, E.R.; AMARAL, J.A.T.; COELHO, R.I. Influência da poda em diferentes alturas no mamoeiro 'Golden'. Revista Ciência Agronômica, Fortaleza, v.4, n.40, p.596-601, 2009. Disponível em: $<$ http://www.ccarevista.ufc.br/seer/index.php/ccarevista/ article/viewFile/418/387>.

BHATTACHARYA, J.; RENUKDAS, N.N.; KHUSPE, S.S.; RAWAL,S.K. Multiple shoot regeneration from immature embryo explants of papaya. Biologia Plantarum, Dordrecht, v.47, n.3, p.327-331, 2003.

BRUIJNE, E.; LANGHE, E. DE.; VAN RIJCK, R. Actions of hormones and embryoid formation in callus cultures of Carica papaya. International Symposium over Fytofarmacie en Fytiatrie, Gent, v.26, p.637-645, 1974.

BUDDENDORF-JOOSTEN, J.M.C.; WOLTERING, E.J. Components of the gaseous environment and their affects on plant growth and development in vitro. Plant Growth Regulation, Dordrecht, v.15, p.1-16, 1994.

CABRERA-PONCE，J.L.; VEGAS-GARCIA.; HERRERA-ESTRELLA, L. Regeneration of transgenic papaya plants via somatic embryogenesis induced by Agrobacterium rhizogenes. In Vitro Cell \& Developmental Biology - Plant, Cambridge, v.32, p.86-90, 1996.

CAI, W.Q.; GONSALVES, C.; TENNANT, P.; FERMIN, G.; SOUZA, M.; SARINDU, N.; JAN F.J.; ZHU H.Y.; GONSALVES, D. A protocol for efficient transformation and regeneration of Carica papaya L. In Vitro Cellular \& Developmental Biology- Plant, Cambridge, v.35, n.1, p.61-69, 1999.

CAPLE, A.D.; CHEAH, K.T. Micropropagation of Hermaphrodite Carica papaya L. 'Rainbow' Seedlings via Axillary Bud Pathway. Biotechnology, Faisalãbãd, v.12, p.1-5, 2016.

CATTANEO, L.F.; COSTA, A.F.S.; SERRANO, L.A.L.; COSTA, A.N.; FANTON, C.J.; BRAVIM, A.J.B. Rubi Incaper 511: primeira variedade de mamão do grupo Formosa para o Espírito Santo. Vitória: Incaper, 2010. 6p. (Série Documentos, 187).

CHAVES-BEDOYA, G.; PULIDO, M.; SÁNCHEZBETANCOURT, E.; NÚÑEZ, V. Marcadores RAPD para la identificación del sexo en papaya (Carica papaya L.) en Colombia. Agronomía Colombiana, Bogotá, v.27, n.2, p.1-5, 2009. Disponível em: $<$ http://www.revistas. unal.edu.co/index.php/agrocol/article/view/11123/11789>> 
CHEN, M.H.; WANG, P.J.; MAEDA, E. Somatic embryogenesis and plant regeneration in Carica papaya L. tissue culture derived from root explants. Plant Cell Reports, Berlin, v.11, p.348-351, 1987.

CHONG, S.T.; PRABHAKARAN, R.; LEE, H.K. An improved technique of propagating 'Eksotika' papaya. Acta Horticulturae, The Hague, v.787, p.273-276, 2008. Disponível em: $\leq$ http://www.ishs.org/ishs-article/787_30>

CLARINDO, W.R.; CARVALHO, C.R. DE.; ARAUJO, F.S.; ABREU, I.S. DE.; OTONI, W.C. Recovering polyploid papaya in vitro regenerants as screened by flow cytometry. Plant Cell, Tissue and Organ Culture, Dordrecht, v.92, p.207-214, 2008.

COSTA, A.F.S.; COSTA, A.N. Propagação Vegetativa do Mamoeiro. In: CONGRESSO BRASILEIRO DE FRUTICULTURA, 14.,1996, Curitiba. Resumos..., Curitiba: SBF, 1996. p. 289.

COSTA, A.F.S.; COSTA, A.N.; SANTOS, F.A.M.; BARRETO, F.C.; ZUFFO, V.J. Plantio, formação e manejo da cultura. In: MARTINS, D.S.; COSTA, A.F.S. (Ed.). A cultura do mamoeiro: tecnologias de produção. Vitória: INCAPER, 2003. p.127-159.

COSTA, A.F.S.; PACOVA, B.E.V. Caracterização de cultivares, estratégias e perspectivas do melhoramento genético do mamoeiro. In: MARTINS, D.S.; COSTA, A.F.S. (Ed.). A cultura do mamoeiro: tecnologias de produção. Vitória: INCAPER, 2003. p.57-102.

DEPUTY, J.C.; MING, R.; MA, H.; LIU, Z.; FITCH, M.M.M.; WANG, M.; MANSHARDT, R.; STILES, J.I. Molecular markers for sex determination in papaya (Carica papaya L.). Theoretical and Applied Genetics, Berlin, v.106, p.107-111, 2002. Disponível em: $\leq$ http://link. springer.com/article/10.1007\%2Fs00122-002-0995-0>.

DHEKNEY, S.A.; KANDEL1, R.; BERGEY, D.R.; SITTHER, V.; SOORINATHASUNDARAM, K.; LITZ, R.E. Advances in Papaya Biotechnology. Biocatalysis and Agricultural Biotechnology, Amsterdam, v. 5, p.133-142, 2016.

DREW, R.A. Rapid clonal propagation of papaya in vitro from mature field grown trees. HortScience, Alexandria, v.23, p.609-611, 1988.

DREW, R.A.; O'BRIEN, C.M.; MAGDALITA, P.M. Development of interspecific Carica hybrids. Acta Horticulturae, The Hague, v.461, p.285-292, 1998.
DREW, R.A.; SIAR, S.V.; DILLON, S.; RAMAGE, C.; O'BRIEN, C. M.; SAJISE, A.G.C. Intergeneric hybridisation between Carica papaya and wild Vasconcellea species and identification of a PRSV-P resistance gene. Acta Horticulturae, The Hague, v.738, p.165-169, 2007.

FITCH, M.; MANSHARDT, R. Somatic embryogenesis and plant regeneration from immature zygotic embryos of papaya (Carica papaya L.). Plant Cell Reports, Berlin, v.9, p.320-324, 1990.

FITCH, M.M.M. High frequency somatic embryogenesis and plant regeneration from papaya hypocotyls callus. Plant Cell, Tissue and Organ Culture, Dordrecht, v.32, p.205-212, 1993.

FITCH, M.M.M.; MOORE, P.H.; LEONG, T.C.H.; AKASHI, A.Y.; YEH, K.F.; WHITE, S.A.; CRUZ, A.S.D.; SANTO, L.T.; FERREIRA, S.A.; POLAND, L.J. Clonally propagated and seed-derived papaya orchards: 1 plant production and field growth. HortScience, Alexandria, v.40, n.5, p.1283-1290, 2005. Disponível em: $\leq$ http:// hortsci.ashspublications.org/content/40/5/1283.full. pdf + html $>$.

FURLANI, P.R.; SILVEIRA, L.C-P.; BOLONHEZI, D.; FAQUIM, V. Cultivo hidropônico de plantas. Campinas: Instituto Agronômico, 1999. 52p. (Boletim Técnico, 180).

GIAMPAN, J.S.; CERQUEIRA, T.S.; JACOMINO, A.P.; REZENDE, J.A.M.; SASAKI, F.M. Indução de brotos laterais em mamoeiro (Carica papaya L.). Revista Brasileira de Fruticultura, Jaboticabal, v.27, n.1, p.185187, 2005. Disponível em: $\leq \mathrm{http} / /$ www.scielo.br/pdf/rbf/ v27n1/24599.pdf $>$.

GRATTAPAGLIA, D.; MACHADO, M. A. Micropropagação. In: TORRES, A. C.; CALDAS, L.; BUSO, J. A. Cultura de tecidos e transformação genética de plantas. Brasília: Embrapa-SPI / EmbrapaCNPH, 1998. v.1, p.183- 260.

HANCOCK, W.G. Grafting male papaw trees. Queensland Agricultural Journal, Brisbane, v.54, n.5, p.377-379, 1940.

HARTMANN, H.T.; KESTER, D.E.; DAVIES JR, F.T.; GENEVE, R.L. Plant propagation: principles and practices. $8^{\text {th }}$ ed. New Jersey: Prentice Hall, 2011. 915p. 
HERINGER, A.S.; VALE, E.M.; BARROSO, T.; SANTACATARINA, C.; SILVERIA, V. Polyethylene glycol effects on somatic embryogenesis of papaya hybrid UENF/ CALIMAN 01 seeds. Theoretical Experimental and Plant Physiology, Berlin, v.25, p.116-124, 2013.

HOMHUAN, S.; KIJWIJAN, B.; WANGSOMNUK, P.; BODHIPADMA, K.; LEUNGC, D.W.M. Variation of plants derived from indirect somatic embryogenesis in cotyledon explants of papaya. Sciencia Asia, Banbgok, v.34, p.347-352, 2008.

JIMÉNEZ, H. Injertos entre especies de Carica. Agricultura Tropical, La Habana, v.7, n.1, p.33-37, 1957.

KATOH, F.; OOISHI, A. A study on juvenility and nodal aging of papaya by vegetative propagation. Journal of the Japanese Society for Horticultural Science, Tokyo, v.72, n.2, p.93-98, 2003. Disponível em: $<$ https://www. jstage.jst.go.jp/article/jishs1925/72/2/72 2 2 93/ pdf $>$.

KOZAI, T. Photoautotrophic micropropagationenvironmental control for promoting photosynthesis. Propagation Ornamental Plants, Sofia, v.10, p.188-204, 2010.

KOZAI, T.; XIAO, Y.; NGUYEN, Q.T.; AFREEN, F.; ZOBAYED, S.M.A. Photoautotrophic (sugar-free medium) micropropagation system for large-scale commercialization. Propagation Ornamental Plants, Sofia, v.5, p.23-34, 2005.

KRISHNA, H.; ALIZADEH, M.; SINGH, D.; SINGH, U.; CHAUHAN, N.; EFTEKHARI, M.; SADH, R.K. Somaclonal variations and their applications in horticultural crops improvement. Biotechnology, Faisalãbãl, v.6, p.54, 2016.

KUMAR, P.R.; KUMAR, S.R.; LOKMAN, H.M. Propagation of papaya (Carica papaya L.) cv. Shahi through in vitro culture. Bangladesh Journal of Botany, Dacca, v.41, p.191-195, 2012.

LAI, C.C.; YEH, S.D.; YANG, J.S. Enhancement of papaya axillary shoot proliferation in vitro by controlling the available ethylene. Botanical Bulletin of Academia Sinica, Nangang, v.41, p.203- 212, 2000.

LAI, C.C.; YU, T.A.; YEH, S.D.; YANG, J.S. Enhancement of in vitro growth of papaya multishoots by aeration. Plant Cell, Tissue and Organ Culture, Dordrecht, v.53, p.221$225,1998$.

LANGE, A.H. Reciprocal grafting of normal and dwarf Solo papaya on growth and yield. HortScience, Alexandria, v.4, n.4, p.304-306, 1969.
LEE, J.M.; KUBOTA, C.; TSAO, S.J.; BIE, Z.; ECHEVARRIA, P.H.; MORRA, L.; ODA, M. Current status of vegetable grafting: Diffusion, grafting techniques, automation. Scientia Horticulturae, Alexandria, v.127, n.2, p.93-105, 2010. Disponível em: $\leq \mathrm{http}: / /$ www.sciencedirect.com/science/article/pii/ $\underline{\text { S0304423810003699 }>\text {. }}$

LIMA, L.A. de; NAVES, R.V.; YAMANISHI, O.K.; PANCOTI, H.L.Behavior of three papaya genotypes propagated by grafting in Brazil. Acta Horticulturae, The Hague, v.851, p.343-348, 2010. Disponível em: $\leq$ http:// www.ishs.org/ishs-article/851_52>

LITZ, R.E.; CONOVER, R.A. Effect of sex type, season and other factors on in vitro establishment and culture of Carica papaya L. explants. Journal of the American Society for Horticultural Science, Alexandria, v.106, p.792-794, 1981.

LITZ, R.E.; CONOVER, R.A. In vitro propagation of papaya. Hortscience, Alexandria, v.13, n.3, p.241-242, 1978.

LITZ, R.E.; CONOVER, R.A. Tissue culture propagation of papaya. Proceedings Florida State Horticultural Society, Lake Alfred, v.90, p.245-246, 1977.

MALABADI, R.B.; KUMAR, S.V.; MULGUND, G.S.; NATARAJA, K. Induction of somatic embryogenesis in Papaya (Carica papaya). Research in Biotechnology, Bethesda, v.2, n.5, p.40-55, 2011.

MEHDI, A.A. Tissue culture of Carica papaya L. HortScience, Alexandria, v.11, p.311, 1975.

MING, R.; HOU, S.; FENG, Y. ET AL. The draft genome of the transgenic tropical fruit tree papaya (Carica papaya Linnaeus). Nature, London, v.452, p.991-997, 2008.

MISHRA, R.; GAUR, R.K.; PATIL, B.L. Current Knowledge of Viruses Infecting Papaya and Their Transgenic Management. Plant Viruses: Evolution and Management, Singapore, p.189-203, 2016.

MONDAL, M.; GUPTA, S.; MUKHERJEE, B.B. In vitro propagation of shoot buds of Carica papaya L. (Caricaceae) var. Honey Dew. Plant Cell Reports, Berlin, v.8, p.609-612, 1990.

MUMO, N.N.; RIMBERIA, F.K.; MAMATI, G.E.; KIHURANI, A.W. In vitro regeneration of selected Kenyan papaya (Carica papaya L.) lines through shoot tip culture. African Journal of Biotechnology, Nairobi,v.12, p.6826-6832, 2013. 
MURASHIGE, T.; SKOOG, F. A revised medium for rapid growth and bioassays with tobacco tissue cultures. Physiologia Plantarum, Copenhagen, v.15, p.473-497, 1962.

NASCIMENTO, A.L.; FERREIRA, J.P.; SCHMILDT, O.; SCHMILDT E.R.; SILVA, C.A. Obtenção de brotações laterais em mamoeiro 'Golden' pela oclusão do caule em plantas adultas. Enciclopédia Biosfera, Goiânia, v.7, n.13, p.255-262, 2011. Disponível em: $\leq$ http://www.conhecer. org.br/enciclop $/ 2011 \mathrm{~b} /$ ciencias $\% 20$ agrarias/obtencao $\% 20$ de\%20brotacoes.pdf $>$.

NAVA, R.; GARCÍA, A.V.; MARÍN, C.R.; VILLEGAS, Z. Propagación clonal de plantas élite de Carica papaya L. usando microinjertación in vitro e in vivo. Interciencia, Caracas, v.36, n.7, p.517-523, 2011. Disponível em: $\leq$ http://www.interciencia.org/v36 07/517.pdf $>$.

NORIKANE, A.; TAKAMURA, T.; MOROKUMA, M.; TANAKA, M. In vitro growth and single-leaf photosynthetic response of Cymbidium plantlets to superelevated $\mathrm{CO} 2$ under cold cathode fluorescent lamps. Plant Cell Reports, Berlin, v.29, p.273-283, 2010.

NZILANI, N.M.; KARAMBU, F.R.; EDWARD, G.M.; WANJIRU, A.K. In vitro regeneration of selected Kenyan papaya (Carica papaya L.) lines through shoot tip culture. African Journal of Biotechnology, Nairobi, v.12, p.6826-6832, 2013.

OLIVEIRA, E.J.; DANTAS, J.L.L.; CASTELLEN, M.S.; LIMA, D.S.; BARBOSA, H.S.; MOTTA, T.B.N. Marcadores moleculares na predição do sexo em plantas de mamoeiro. Pesquisa Agropecuária Brasileira, Brasília, DF, v.42, n.12, p.1747-1754, 2007. Disponível em: <http://www.scielo.br/pdf/pab/v42n12/a12v4212. pdf $>$.

OLIVEIRA, M.J.V. Enraizamento de microestacas e miniestacas de mamoeiro hibrido Uenf/Caliman 02. 2014. 101f. Tese (Doutorado em Produção Vegetal) Universidade Federal do Espírito Santo, Alegre. 2014. Disponível em: $<$ http://portais4.ufes.br/posgrad/teses/ tese 7452 Marcio\%20Jose $\% 20$ Vieira $\% 20$ de $\% 20$ Oliveira.pdf $>$.

ONO, E. O.; GRANA JÚNIOR, J. F.; RODRIGUES, J.D. Reguladores vegetais na quebra da dominância apicalde mamoeiro (Carica papaya L.). Revista Brasileira de Fruticultura, Jaboticabal, v.26, n.2, p. 348-350, 2004. Disponível em: $\leq \mathrm{http}: / / \mathrm{www} . \mathrm{scielo.br} / \mathrm{pdf} / \mathrm{rbf} /$ v26n2/21841.pdfs.
PATEL, J.R.; PATEL, R.M.; PATEL, S.R.; SINGH, V. In vitro micro propagation of papaya var. Red Lady. International Journal of Plant Protection, Muzaffarnagar, v.6, n.2, p.449-456, 2013.

PEÇANHA, A.L.; CAMPOSTRINI, E.; TORRES NETTO, A.; YAMANISHI, O.K.; LIMA, L.A.; NAVES, R.V. Gas-exchange and photochemical efficiency in seedling and grafted papaya tree grown under field condition. Acta Horticulturae, The Hague, v.851, p.271-278, 2010. Disponível em: $<\underline{\text { http://www.ishs.org/ }}$ ishs-article/851 41>.

PÉREZ, L.P.; MONTESINOS, Y.P.; OLMEDO, J.G.; RODRIGUEZ, R.B.; SÁNCHEZ, R.R.; MONTENEGRO, O.N.; ESCRIBA, R.C.R.; DANIELS, D.; GÓMEZKOSKY, R. Effect of phloroglucinol on rooting and in vitro acclimatization of papaya (Carica papaya $\mathrm{L}$. var. Maradol Roja). In Vitro Cellular \& Developmental Biology Plant, Heidelberg, v.52, p.196-203, 2016.

PÉREZ, L.P.; MONTESINOS, Y.P.; OLMEDO, J.G.; ROMELIO RODRÍGUEZ SÁNCHEZ, R.R.; MONTENEGRO, O.N.; RODRIGUEZ, R.B.; RIBALTA, O.H.; ESCRIBA, R.C.R.; DANIELS, D.; GÓMEZKOSKY, R. Effects of different culture conditions (photoautotrophic, photomixotrophic) and the auxin indole-butyric acid on the in vitro acclimatization of papaya (Carica papaya L. var. Red Maradol) plants using zeolite as support. African Journal of Biotechnology, Nairobi, v. 14, n.35, p.2622-2635, 2015.

RAMKHELAWAN E.; BAKSH N.; LAUCKNER, B. Propagation of papaya (Carica papaya L.) by in vivo methods in Trinidad. Tropical Agriculture, London, v.76, n.2, p.126-130, 1999. Disponível em: $\leq \mathrm{http}: / /$ cat.inist.fr/ ?aModele $=$ afficheN\&cpsidt $=1397086>$.

RAZALI, R.M.; DREW, R. A refined protocol for embryogenesis to transfer PRSV-P resistance genes from Vasconcella pubescens to Carica papaya. Acta Horticulturae, The Hague, v.1022, p.47-53, 2014.

REUVEnI, O.; SHLESINGER, D.R. Rapid vegetative propagation of papaya plants by cuttings. Acta Horticulturae, The Hague, v.275, p.301-306, 1990. Disponível em: <http://www.actahort.org/ books $/ 275 / 275 \quad 36 . h t m>$

RICELLI, M. Injertos entre espécies de Caricaceae. Agricultura Tropical, Ciudad de la Habana, v.13, n.3, p.157-161, 1963. 
RIMBERIA, F. K.; SUNAGAWA, H.; URASAKI, N.; ISHIMINE, Y.; ADANIYA, S. Embryo induction via anther culture in papaya and sex analysis of the derived plantlets. Scientia Horticulturae, New York, v.103, p.199-208, 2005.

ROBLEDO, J.D.; GONZÁLEZ, J.M.H. Papaya. In: ROBLEDO, J.D.; GONZÁLEZ, J.M.H. (Ed.). Frutos tropicales em la Costa Andaluza. Madrid: NormaCapitel, 2009. p.161-166.

ROHMAN, M.M.; ISLAM, Md.N.; ALAM, Md.S.; AHMAD, M.R; PAUL, K. Lateral bud culture of papaya (Carica papaya L.) for clonal propagation. Biotechnology, Faisalãbãd, v.6, n.3, p.339-34, 2007.

SATO, M.; HOSOKAWA, M.; DOI, M. Somaclonal variation is induced de novo via the tissue culture process: a study quantifying mutated cells in Saintpaulia. PLoS One, San Francisco, v.6, n.2, p.35-41, 2011 b.

SCHELLENBAUM, P.; MOHLER, V.; WENZEL, G.; WALTER, B. Variation in DNA methylation patterns of grapevine somaclones (Vitis vinifera L.). BMC Plant Biology, London, v.8, p.78, 2008.

SCHMILDT, E.R.; AMARAL, J.A.T.; SCHMILDT, O. Sucrose on in vitro rooting phase of papaya tree 'Tainung 01'. Scientia Agraria, Curitiba, v.8, p.25-31, 2007.

SCHMILDT, E.R.; SCHMILDT, O.; ALEXANDRE, R.S.; AMARAL, J.A.T.; CAMPOSTRINI, E.; FERREGUETTI, G.A.; GONZÁLEZ, J.C. Propagação assexuada de mamoeiro. In: ZUCOLOTO, M.; SCHMILDT, E.R.; COELHO, R.I.(Ed.). Fruticultura tropical: diversificação e consolidação. Alegre: CAUFES, 2015. p.157-175.

SCHMILDT, O.; CAMPOSTRINI, E.; SCHMILDT, E.R.; TORRES NETTO, A.; PEÇANHA, A.L.; FERRAZ, T.M.; FERREGUETTI, G.A.; ALEXANDRE, R.S.; GONZÁLEZ, J.C. Effects of indol butyric acid concentration on propagation from cuttings of papaya cultivars 'Golden' and 'Uenf/Caliman 01'. Fruits, Paris, v.71, n.1, p.27-33, 2016. Disponível em: $<$ http://www. pubhort.org/fruits/2016/1/fruits150043.htm>.

SCHMILDT, O.; SILVA, C.A.; FERREGUETE, G.A.; SCHMILDT, E.R.; CZEPAK, M.P. Correlação canônica entre caracteres vegetativos e de Capacidade de brotação em mamoeiro. Enciclopédia Biosfera, Goiânia, v.7, n.13, p.255-262, 2011. Disponível em: < $\underline{\text { http://www. }}$ conhecer.org.br/enciclop/2011b/ciencias\%20agrarias/ correlacao $\% 20$ canonica.pdf $>$.
SEKELI, R.; ABDULLAH, J.O.; NAMASIVAYAM, P.; MUDA, P.; ABUBAKAR, U.M. Better rooting procedure to enhance survival rate of field grown Malaysian Eksotika papaya transformed with 1-Aminocyclopropane-1carboxylic acid oxidase gene. ISRN Biotechnology, Cairo, v.13, p.1-10, 2013.

S E N T H I L K UM A R, S .; KUMAR, N .; SOORIANATHASUNDARAM, K.; KUMAR, K.A. Grafted papayas: a boon for dioecious papaya industry. Current Science, Middletwon, v.111, n.8, p.1287-1288,

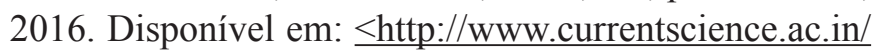
Volumes/111/08/1287.pdf $>$.

S E N T H I L K UMA R, S .; KUMAR, N .; SOORIANATHASUNDARAM, K.; KUMAR, P.J. Aspects on asexual propagation in papaya (Carica papaya L.) - a review. Agricultural Reviews, Karnal, v.35, n.4, p.307- 313, 2014. Disponível em: $<$ http://arccjournals. com/uploads/articles/R1418.pdf>.

SERTAGIE, A.; MEKBIB, F.; ABRAHA, E. In vitro propagation of papaya (Carica papaya L.). World Journal of Agricultural Sciences, Belihuloya, v.11, n.2, p.84-88, 2015.

SHIN, K.S.; PARK, S.Y.; PAEK, K.Y. Sugar metabolism, photosynthesis, and growth of in vitro plantlets of Doritaenopsis under controlled microenvironmental conditions. In vitro Cellular \& Developmental Biology - Plant, Heidelberg, v.49, p.445-454, 2013.

SMULDERS, M.; DE KLERK, G. Epigenetics in plant tissue culture. Plant Growth Regulators, Sofia, v.63, p.137-146, 2011.

SOOKMARK, S.; TAI, E.A. Vegetative propagation of papaya by budding. Acta Horticulturae, The Hague, v.49, p.85-90, 1975. Disponível em: $<$ http://www.actahort.org/ books/49/49 10.htm>

SOUZA JUNIOR., M.T.; NICKEL, O.; GONSALVES, D. Development of virus resistant transgenic papayas expressing the coat protein gene from a Brazilian isolate of Papaya ringspot virus. Fitopatologia Brasileira, Brasília, DF, v.30, p.357-365, 2005.

STOREY, W.B. Papaya. In: SIMMONDS, N. (Ed.). Evolution of crop plants. London: Longman, 1976. p. 21-24.

STOREY, W.B. The primary flower types of papaya and the fruittypes that develop from them. Proceedings of the American Society for Horticultural Science, Geneva, v.35, p.80-82, 1938. 
TEIXEIRA DA SILVA, J.A. Callus induction in papaya (Carica papaya L.), and synseed production for low temperature storage and cryopreservation. Folia Horticulturae, Krakow, v.26, n.2, p.155-162, 2014b.

TEIXEIRA DA SILVA, J.A. In vitro response of papaya (Carica papaya) to plant growth regulators. Nusantara Bioscience, Surakarta, v.8, n.1, p.77-82, 2016. (1)

TEIXEIRA DA SILVA, J.A. Photoauto, Photohetero and Photomixotrophic in vitro propagation of papaya (Carica papaya L.) and response of seed and seedlings to lightemitting diodes. Thammasat International Journal of Science and Technology, Bangkok, v.19, p.57-71, 2014.

TEIXEIRA DA SILVA, J.A.; GIANG, D.T.T.; CHAN, M.T.; SANJAYA, N.A.; CHAI, M.L.; CHICO-RUÍZ, J.; PENNA, S.; GRANSTROM, T.; TANAKA, M. The influence of different carbon sources, photohetero-, photoauto and photomixotrophic conditions on protocormlike body organogenesis and callus formation in thin cell layer culture of hybrid Cymbidium (Orchidaceae). Orchid Science and Biotechnology, Isleworth, v.1, n1-2, p.1523, 2007.

TETSUSHI, H., SADAO, K., MASAHIKO, Y., HIROSHI, F. Mass production of papaya (Carica papaya L.) saplings using shoot tip culture for commercial use. South Pacific Studies, Kagoshima, v.28, p.87-95, 2008.

THOMAS, P.; KUMARI, S. Inconspicuous endophytic bacteria mimicking latex exudates in shoot-tip cultures of papaya. Scientia Horticulturae, New York, v.124, p.469-474, 2010.

THOMAS, P.; KUMARI, S.; SWARNA, G.K.; PRAKASH, D.P.; DINESH, M.R. Ubiquitous presence of fastidious endophytic bacterial in field shoots and index-negative apparently clean shoot-tip cultures of papaya. Plant Cell Reports, Berlin, v.26, p.1491-1499, 2007.

TSAI, S.F.; YEH, S.D.; CHAN, C.F.; LIAW, S.I. High efficiency vitrification protocols for cryopreservation of in vitro grown shoot tips of transgenic papaya lines. Plant Cell, Tissue and Organ Culture, Dordrechtm v.98, p.157-164, 2009.

TSAY, H.S.; SUE, C.Y. Anther culture of papaya (Carica papaya L.). Plant Cell Reports, Berlin, v.4, p.28-30, 1985.
VALE, E.M.; HERINGER, A.S.; BARROSO, T.; FERREIRA, A.T.S.; COSTA, M.N.; PERALES, J.E.A.; SANTA-CATARINA, C.; SILVEIRA, V. Comparative proteomic analysis of somatic embryo maturation in Carica papaya L. Proteome Science, La Jolla, v.12, p.37-53, 2014.

VAN DROOGENBROECK, B.; BREYNE, P.; GOETGHEBEUR, P. ; ROMEIJN-PEETERS, E.; KYDNT, T.; GHEYSEN, G. AFLP analysis of the genetic relationships among papaya and its wild relatives (Caricaceae) from Ecuador. Theoretical and Applied Genetics, Berlin, v.105, p.289-297, 2002.

VAN DROOGENBROECK, B.; MAERTENS, I.; HAEGEMAN, A.; KYNDT, T.; O'BRIEN, C.; DREW, R.A.; GHEYSEN, G. Maternal inheritance of cytoplasmic organelles in intergeneric hybrids of Carica papaya L. and Vasconcellea spp. (Caricaceae Dumort., Brassicales). Euphytica, Dordrecht, v.143, p.161-168, 2005.

VEENA, G.L.; DINESH, M.R.; KUMAR, R.A. Axillary bud culture in papaya. Bioinfolet, New Delhi, v.12, p.147$149,2015$.

VILASINI, P.; LATIPAH, Z.; SALASIAH, A. Induction of somatic embryogenesis and plant regeneration from immature embryos of Eksotika papaya (Carica papaya). Journal of Tropical and Food Sciences, Kuala Lumpur, v.28, n.2, p.121-126, 2000.

WU, K.; ZENG, S.; CHEN, Z.; DUAN, J. In vitro mass propagation of hermaphroditic Carica papaya cv. Meizhonghong. Pakistan Journal of Botany, Karachi, v.44, n.5, p.1669-1676, 2012.

YIE, S.T.; LIAW, S.I. Plant regeneration from shoot tips and callus of papaya. In vitro, Columbia, v.13, p.564568, 1977.

YU, Q.; TONG, E.; SKELTON, R.L.; BOWERS, J.E.; ET AL. A physical map of the papaya genome with integrated genetic map and genome sequence. BMC Genomics, London, v.10, p.1-12, 2009.

ZOBAYED, S.M.A.; AFREEN, F.; XIAO, Y.; KOZAI, $T$. Recent advancement in research on photoautotrophic micropropagation using large culture vessels with forced ventilation. In vitro Cellular \& Developmental Biology Plant, Cambridge, v.40, p.450-458, 2004. 